PRZEGLĄD NAUK HISTORYCZNYCH 2016, R. XV, NR 1

http://dx.doi.org/10.18778/1644-857X.15.01.11

ILONA FLORCZAK

(UNIWERSYTET ŁóDZKI)*

\title{
Z listów Zygmunta Glogera do Juliana Bartoszewicza
}

ygmunt Gloger (1845-1910), znany etnograf, archeolog, badacz
starożytności słowiańskich, pochodził z Podlasia. Z tym tere-
nem związany był również Julian Bartoszewicz (1821-1870), $z$ zawodu nauczyciel, $z$ zamiłowania zaś historyk, publicysta i kolekcjoner. Właśnie pasja kolekcjonerska i zainteresowania przeszłością narodu polskiego zbliżyły dwóch miłośników dziejów ojczyzny. Obaj wysoko cenili wartość źródeł historycznych i podejmowali kroki w celu ich odnalezienia i ocalenia od zniszczenia. Między dwoma Podlasiakami $z$ pochodzenia nawiązała się bliska więź oparta na wspólnych zainteresowaniach i wzajemnej sympatii i szacunku. W jej utrzymaniu nie przeszkadzało to, że Zygmunt Gloger był ponad 20 lat młodszy od Juliana Bartoszewicza.

Zapewne Gloger spotykał historyka w Warszawie w okresie nauki w prywatnej szkole J.N. Leszczyńskiego, do której uczęszczał od 1858 r. Niewykluczone, że jego ojciec Jan, uczeń szkoły wydziałowej w Białej Podlaskiej i wychowanek Adama Bartoszewicza, polecił swego syna opiece rodzinie znanego pedagoga. $Z$ pewnościa Julian Bartoszewicz wywarł duży wpływ na zainteresowania Zygmunta Glogera. W czasie, gdy młody student rozpoczynał dopiero poważne badania w zakresie historii, etnografii i archeologii, gdy kształtowały się jego zainteresowania badawcze, Julian Bartoszewicz był już uznanym autorytetem w dziedzinie historii i badań źródłowych. Był też cenionym kolekcjonerem i znawca archiwaliów, specjalistą

* Wydział Filozoficzno-Historyczny, Instytut Historii, Katedra Historii Historiografii i Nauk Pomocniczych Historii. 
w odnajdywaniu i porządkowaniu zapomnianych manuskryptów. Pasja kolekcjonerska, z której byli znani Bartoszewiczowie, była bardzo popularna w owym czasie na ziemiach polskich. Nic więc dziwnego, że uległ je także młody Gloger, tym bardziej że kolekcjonerstwo było również pasją jego ojca ${ }^{1}$. Wspólne zainteresowania były więc jednym $z$ głównych powodów bliskich i serdecznych kontaktów między wspomnianymi badaczami. Biografowie Zygmunta Glogera zwracają także uwagę na te cechy charakteru młodego Podlasianina, które zjednywały mu sympatię nowo poznanych ludzi i dzięki którym mógł nawiązać nie tylko liczne kontakty towarzyskie, lecz także naukowe ${ }^{2}$.

Po ukończeniu szkoły Leszczyńskiego, w latach 1865-1867 Zygmunt Gloger kontynuował naukę w Warszawskiej Szkole Głównej na Wydziale Prawa i Administracji, a następnie przeniósł się do Krakowa, gdzie postanowił poświęcić się studiowaniu historii $\mathrm{i}$ archeologii. Do Galicji Gloger przyjechał $z$ pewnym dorobkiem naukowym - od 1867 r. publikował artykuły, głównie o tematyce etnograficznej, w periodykach Królestwa Polskiego, m.in. „Bibliotece Warszawskiej"3. W krakowskie środowisko naukowe młodego etnografa wprowadzili Oskar Kolberg ${ }^{4}$ i Karol Estreicher ${ }^{5}$, profesor

${ }^{1}$ W. Ols zewicz, Życie i praca Zygmunta Glogera, [w:] Zygmunt Gloger - badacz przeszłości ziemi ojczystej, Warszawa 1978, s. 8.

2 T. Ko morows ka, Zygmunt Gloger. Opowieść biograficzna, Warszawa 1985, passim.

${ }^{3}$ Pierwszym tekstem, który ukazał się na łamach tego warszawskiego periodyku, był artykuł dotyczacy obrzędów rolniczych na Podlasiu (Z. Gloger, Obrzędy rolnicze, „Biblioteka Warszawska” 1867, t. II, s. 274-287). Biografowie Glogera podaja informację, że jego pierwszym ogłoszonym drukiem tekstem był szkic poświęcony pomnikowi Stefana Czarneckiego w Tykocinie. Tymczasem artykuł został podpisany przez Ludwika Jenikego (1818-1903), redaktora „Tygodnika Ilustrowanego". Por. Pomnik Stefana Czarnieckiego w Tykocinie, „Tygodnik Ilustrowany" 1863, t. VIII, s. 365-366.

${ }^{4}$ R. Żurkowa, Zygmunta Glogera zwiazki z AU w Krakowie, „Rocznik Biblioteki Polskiej Akademii Nauk w Krakowie” 1973, t. XIX, s. 136. Oskar Kolberg (1814-1890) - etnolog, etnograf, kompozytor, kolekcjoner. M. Tu r c zy now i c z ow a, Kolberg Henryk Oskar, [w:] Polski słownik biograficzny [dalej: PSB], t. XIII, Wrocław i in. 1967-1968, s. 300-304.

${ }^{5}$ Karol Estreicher (1827-1908) - polski historyk literatury, profesor zwyczajny UJ, twórca Bibliografii Polskiej. Zanim obją stanowisko dyrektora Biblioteki Uniwersytetu Jagiellońskiego (1868-1905), był dyrektorem Biblioteki Szkoły Głównej w Warszawie (1862-1868). A. Birken majer, Estreicher Karol, [w:] PSB, t. VI, Kraków 1946, s. 312-315. Warto dodać, że jednym z jego współpracowników w bibliotece w Warszawie był Julian Bartoszewicz, zatrudniony w niej jako kustosz w latach 1863-1868. 
tamtejszego uniwersytetu i dyrektor Biblioteki Jagiellońskiej, znajomi z okresu pobytu w Warszawie. Gloger bardzo szybko nawiazał kontakty z przedstawicielami świata nauki, m.in. z profesorami Uniwersytetu Jagiellońskiego: archeologiem Józefem Łepkowskim ${ }^{6}$ czy historykiem Józefem Szujskim ${ }^{7}$. Był zapraszany na spotkania Towarzystwa Naukowego Krakowskiego ${ }^{8}$, a po utworzeniu w jego łonie Komisji Historycznej został jej członkiem. Na marginesie można dodać, że Komisji przewodniczył Józef Szujski. Znajomość Glogera $z$ krakowskim historykiem trwała przez kolejne lata9 .

Korespondencja między warszawskim historykiem i przebywającym w Krakowie Glogerem obejmuje lata 1869-1870. Tematyka publikowanych listów związana jest w dużej mierze $z$ podjętymi przez Juliana Bartoszewicza staraniami o objęcie katedry uniwersyteckiej w Krakowie. W 1869 r. był on na emeryturze, rok wcześniej został zwolniony ze służby państwowej ${ }^{10}$. W tym czasie nadal dużo pracował naukowo, publikował w różnych periodykach warszawskich, porzadkował zgromadzone zbiory i archiwa przyjaciół i tworzył kolejne prace. Wiele $z$ nich pozostawało jednak w rękopisie. Coraz częściej zmagał się też historyk $z$ problemami zdrowotnymi ${ }^{11}$. Zygmunt Gloger pozostawał pod wrażeniem dorobku naukowego Bartoszewicza i jego niezwykłej pracowitości i wytrwałości w poszukiwaniu i odczytywaniu źródeł. Starał się więc wspomóc warszawskiego dziejopisa w uzyskaniu posady kierownika Katedry Historii

${ }^{6}$ Łepkowski Józef - archeolog, historyk, profesor zwyczajny i rektor Uniwersytetu Jagiellońskiego. Był kierownikiem katedry archeologicznej w tej uczelni. C. Koczarska-Bak, Łepkowski Józef, [w:] PSB, t. XVIII, Wrocław i in. 1973, s. 339-343.

7 Szujski Józef (1835-1883), [w:] PSB, t. LXIX, Warszawa-Kraków 2013, s. $176-187$.

8 Towarzystwo powstało w 1815 r., skupiało przedstawicieli środowiska naukowego $z$ Galicji. Działało w ścisłym związku $z$ Uniwersytetem Jagiellońskim, do tego stopnia, że do 1852 r. kolejni rektorzy uczelni byli prezesami Towarzystwa. W roku 1872 zostało przekształcone w ponadzaborowa Akademię Umiejętności (K.K. Das zyk, Historiografia krakowska doby zaborów. Główne kierunki badań i interpretacji narodowej przeszłości, [w:] Historiografia Krakowa i jej twórcy, Kraków 2005, s. 35).

${ }^{9}$ A. Żurkowa, op. cit., s. $138-139$.

10 I. Florczak, Nauczyciel w służbie państwowej. Między poczuciem obowiazku a własnymi aspiracjami. Przypadek Juliana Bartoszewicza (1821-1870), [w:] Między irredenta a kolaboracja. Ugoda, legalizm, lojalizm. „Dusza urzędnika” - ludzie $i$ ich kariery, red. A. Szmyt, Olsztyn 2015, s. 62.

${ }^{11}$ Listy Juliana Bartoszewicza, [w:] Ksiega pamiatkowa na uczczenie setnej rocznicy urodzin Adama Mickiewicza (1798-1898), t. I, Warszawa 1898, s. 115. 
Polski. Uważał, że Bartoszewicz był właściwym kandydatem, z odpowiednim przygotowaniem merytorycznym i osiagnięciami, które predestynowały go do zajęcia stanowiska profesora na wyższej uczelni. Na marginesie można dodać, że jako jedyny ze zgłoszonych wówczas kandydatów miał dyplom ukończenia studiów na wyższej uczelni ${ }^{12}$. W zwiazku $z$ tym Gloger „pilnował sprawy” na miejscu, czyli w Krakowie, dokad przybył, jak wspomniano, w 1868 r.

Sprawa utworzenia Katedry Historii Polski poruszyła polskie środowisko historyczne nie tylko w Galicji. Po raz pierwszy bowiem na wyższej uczelni powołano osobną jednostkę zajmującą się dziejami Polski. Był to kolejny krok ku autonomii narodu polskiego wprowadzanej w Galicji od 1867 r. W celu obsadzenia katedry Wydział Filozoficzno-Historyczny UJ powołał specjalną komisję, która miała się zająć poszukiwaniem "odpowiedniego kandydata”"13. Informacje o możliwości objęcia katedry uniwersyteckiej Julian Bartoszewicz otrzymał już w kwietniu 1869 r. od Lucjana Siemieńskiego ${ }^{14}$, który w liście do warszawskiego historyka obiecał wstawiennictwo w ewentualnym uzyskaniu poparcia wpływowych osobistości w Wiedniu. Biograf Józefa Szujskiego, kontrkandydata do kierowania Katedra Historii Polski, uznał, że propozycja złożona Bartoszewiczowi wynikała $z$ chęci „utemperowania” Szujskiego ${ }^{15}$. Warszawski historyk

${ }^{12}$ W latach 1838-1842 Julian Bartoszewicz studiował na Uniwersytecie Petersburskim jako stypendysta Królestwa Polskiego. Po czterech latach otrzymał tytuł kandydata nauk tejże uczelni. Archiwum Państwowe w Łodzi [dalej: APŁ], Archiwum rodziny Bartoszewiczów, sygn. 807.

${ }^{13}$ Szczegółowe kwestie zwiazane $z$ utworzeniem katedry, powołaniem komisji, jej składem i działalnością: H.S. Michalak, Józef Szujski 1835-1883. Światopogląd i działanie, Łódź 1987, s. 197-200.

14 Siemieński Lucjan (1807-1877) poeta, krytyk literacki, tłumacz, nowelista, członek Towarzystwa Naukowego Krakowskiego, współzałożyciel i członek Akademii Umiejętności, związany z krakowskim konserwatystami, współpracownik „Czasu” i „Przeglądu Polskiego”, w latach 1848-1850 profesor literatury powszechnej UJ.

15 Józef Szujski był jednym z założycieli „Przeglądu Polskiego” (1866) - organu „młodych” konserwatystów krakowskich, którzy głosili potrzebę współpracy z rządem austriackim i wprowadzenia autonomii Galicji. Ten program, uogólniając, zakładał ugodowa postawę wobec władz. Szujski, w okresie starań o wprowadzenie autonomii galicyjskiej, w swych wypowiedziach krytykował nadmierne zaufanie pokładane w rządzie austriackim. Ponadto coraz częściej reprezentował antyniemieckie stanowisko (w sytuacji, gdy w grę wchodziła szeroko rozumiana obrona polskości). To odrębne stanowisko, nie do końca zgodne z politycznymi zapatrywaniami konserwatystów krakowskich, mogło, jak twierdził Henryk S. Michalak, być powodem próby utrudnienia Szujskiemu zdobycia katedry uniwersyteckiej (H.S. Michalak, op. cit., s. 196-198). 
wyraził zainteresowanie propozycją i zgłosił swój akces ${ }^{16}$. Trzecim kandydatem był Henryk Schmitt, galicyjski historyk i publicysta jego kandydatura upadła ze względu na uchybienia formalne ${ }^{17}$. Na posiedzeniu komisji w dniu 17 lipca poparto kandydaturę Józefa Szujskiego. Tydzień później na posiedzeniu wydziału ostatecznie i jednogłośnie podjęto decyzję o zatrudnieniu krakowskiego historyka $^{18}$. Wybór, w ocenie historyków, okazał się wyjątkowo trafny - jeden $z$ twórców krakowskiej szkoły historycznej, obok niewątpliwych zasług na polu naukowym, okazał się też nieprzeciętnym pedagogiem $^{19}$.

W publikowanych niżej listach przekazywał więc Bartoszewiczowi wieści i informacje dotyczące rozwoju sytuacji, nastrojów wśród grona decyzyjnego i krakowskiego środowiska naukowego ${ }^{20}$. Przy okazji, jako Królewiak, nie omieszkał wytknać przywar Polakom z zaboru austriackiego - ich megalomanii i poczucia wyższości nad przedstawicielami narodu $z$ pozostałych zaborów. Taki wizerunek krakowskich uczonych i tamtejszego środowiska naukowego wyłania się z listów młodego Glogera do doświadczonego historyka.

${ }^{16}$ List Juliana Bartoszewicza do Józefa Kremera z 12 maja 1869 r., [w:] „Krynica Wiadomości". Korespondencja Józefa Kremera z lat 1834-1875, oprac. Z. Sudolski, Kraków 2007, s. 236. W archiwum rodzinnym Bartoszewiczów przechowywany jest również brudnopis podania, jakie historyk złożył do Wydziału Filozoficznego. $\mathrm{Na}$ piśmie widnieje data 29 czerwca 1869 r. (APŁ, Archiwum Bartoszewiczów, sygn. 812, k. 1-2).

17 Henryk Schmitt nie złożył odpowiedniej dokumentacji i nie miał ukończonych studiów wyższych, w zwiąku z tym obradujacca w połowie lipca 1869 r. komisja odrzuciła jego kandydaturę. Por. H.S. Michalak, op. cit., s. 200; S. Kieniewicz, Schmitt Henryk (1817-1883), [w:] PSB, t. XXXV, Warszawa-Kraków 1994, s. 561. Warto w tym miejscu dodać, że również Józef Szujski nie miał dyplomu ukończenia studiów wyższych. Mimo to habilitował się tuż przed uzyskaniem stanowiska kierownika Katedry Historii Polski (Szujski Józef.., s. 177; H.S. Mich ala k, op. cit., s. 198).

18 Ibidem, s. 200.

19 Studia $z$ dziejów Wydziału Filozoficzno-Historycznego Uniwersytetu Jagiellońskiego, red. S. Mikucki, „Zeszyty Naukowe Uniwersytetu Jagiellońskiego”, Prace historyczne 1967, t. CXXXIX, z. 16, s. 119; J. Hulewicz, Seminarium historyczne UJ w latach 1861-1918, [w:] Spór o historyczna szkołe krakowska. W stulecie Katedry Historii Polski UJ 1869-1969, red. C. Bobińska i J. Wyrozumski, Kraków 1972, s. 50. Szerzej na temat działalności dydaktycznej i badawczej Józefa Szujskiego: J. Mitkowski, Józef Szujski jako historyk średniowiecza, [w:] ibidem, s. 71-81; J.A. Gierowski, Józef Szujski jako historyk czasów nowożytnych, [w:] ibidem, s. 83-93.

${ }^{20}$ Pisał o tym, przy okazji recenzji rozprawy J. Maternickiego, A.F. Grabski. A.F. Grabski, Warszawskie środowisko historyczne w okresie międzypowstaniowym, „Kwartalnik Historyczny” 1971, nr 4, s. 895-896. 
Pochodzący z Podlasia, więc z Królestwa Polskiego, etnograf i kolekcjoner, nakreślił niezbyt pochlebny obraz mieszkańców Galicji, podkreślając widoczne różnice w mentalności Polaków z różnych zaborów. W podobny sposób na Galicjan patrzyli inni mieszkańcy Królestwa, także Bartoszewicz.

Publikowane listy są częścią Archiwum rodziny Bartoszewiczów, znajdującego się w zasobach Archiwum Państwowego w Łodzi. Podczas opracowywania korespondencji uwspółcześniono interpunkcję i ortografię. Aby oddać styl, pozostawiono oryginalną formę gramatyczną wyrazów. W tekście rozwinięto stosowane przez autora skróty, umieszczając brakujące fragmenty słów w nawiasach kwadratowych. W odwołaniach wprowadzono niezbędne wyjaśnienia dotyczące osób, miejscowości i innych zagadnień wymagających wytłumaczenia.

$$
* * *
$$

1.

APŁ, Archiwum rodziny Bartoszewiczów, sygn. 1338, k. 4-5.

Kraków, dnia 20 maja 1869 r.

\section{Drogi i Szanowny Panie!}

Od kilku dni przybył tu pan Kazimierz ${ }^{1}$ i doręczył mi listy od Drogiego Pana i Adasia S. ${ }^{2}$ Pan Kazimierz zają się tu gorliwie interesem Drogiego Pana, ale nic stanowczego dotąd nie ma, nic więc nie pisał, bo chciałby już o czym donieść, mówił mi tylko, abym zawiadomił Drogiego Pana, że tu będą jutro potrzebować zebranych wszystkich Jego prac. Radził zatem, aby Szanowny Pan przygotował i zebrał wszystkie monografie i dzieła tak wydane osobno, jak i w Encyklopedii ${ }^{3}$ umieszczone (główniejsze). Zebrane to wszystko (choćby paczka była spora) będzie można przesłać przez sekretarza Szkoły

[1] ${ }^{1}$ Kazimierz Władysław Wójcicki (1807-1879) - literat i wydawca, długoletni redaktor naczelny „Biblioteki Warszawskiej”. Prowadził w Warszawie jeden z salonów, gdzie spotykali się najwybitniejsi intelektualiści ówczesnej Warszawy.

2 Adam Starzeński - pochodzacy z Podlasia, przyjaciel Zygmunta Glogera.

${ }^{3}$ Mowa o 28-tomowej encyklopedii powszechnej, wydawanej przez Samuela Orgelbranda w Warszawie w latach 1859-1868. Jak obliczyli biografowie Bartoszewicza, umieścił on w niej 1291 artykułów, głównie haseł o tematyce historycznej, w tym wiele biogramów postaci historycznych. 
Głównej, który książki wysyła do Estreichera ${ }^{4}$ dla Biblioteki Jagiellońskiej. Estreicher sam to zaprojektował i nadmienił, że to żadnych kosztów pociagnać nie ma. P.[an] Kazimierz zabawi tu jeszcze tydzień, stąd jedzie do Lwowa, a dopiero koło 29 czerwca powróci do Warszawy, będzie pisał wtedy, gdy rzecz się lepiej wyjaśni. Co do mnie, to moge tylko powiedzieć, że między uczonymi znalazłem tu wiele nieuctwa, nie zawsze $z$ bliska się to świeci, co $z$ daleka; same intrygi i prywata, dla dobra ogółu nikt prawie tu nie pracuje. O Szmicie ${ }^{5}$ [s] nikt tu ani myśli, jedni chyba studenci, którym trafia on swoimi tendencjami do smaku ${ }^{6}$; o innych także nie ma mowy kandydatach, widzą tylko dwóch panów, tj. Szujskiego i Drogiego Pana. Nie mogę dziś sądzić, któremu $z$ panów oddadzą posadę, wiedzac, że tu nie zasługa, ale grzeczne słówka popłacaja, rozstrzygnie się to za kilka tygodni, a tymczasem pan Kazimierz serdecznie się krzata w interesie Drogiego Pana i bardzo kazał prosić o zgromadzenie wszystkich prac i przesłanie choćby zaraz do Estreichera. Jak przekonałem się, to niektórzy $z$ wyborców nawet nie słyszeli o wielu szanownych dziełach Drogiego Pana, takie tu jest nieuctwo i zamknięcie się w obrębie literatury krakowskiej. Z Encyklopedii prosił p. Kaz[imierz] najmniej o 20 artykułów.

Co do Szkicu dziejów k.[ościoła] r.[uskiego] ${ }^{7}$, to nic nie moge donieść, bo z Poznania nic nie odebrałem, lecz ponieważ być może, że w końcu czerwca sam będę w Poznaniu, prosiłbym więc o bilecik do posiadającego resztę rękopisu, aby mi to wydał. O Karwickim ${ }^{8}$ już

${ }^{4}$ W rękopisie - Estrajcher. Karol Estreicher (1827-1908) - polski historyk literatury, dyrektor Biblioteki Szkoły Głównej w Warszawie (1862-1868), Biblioteki Uniwersytetu Jagiellońskiego (1868-1905), profesor zwyczajny UJ, twórca Bibliografii Polskiej.

${ }_{5}$ Por. przyp. nr 17 (wprowadzenie).

${ }^{6}$ Mowa zapewne o demokratycznych poglądach $\mathrm{H}$. Schmitta, trudnych do zaakceptowania przez konserwatywne środowisko uniwersyteckie (S. Kieniewicz, op. cit., s. 561).

7 Chodzi o dzieło Juliana Bartoszewicza pt. Szkic dziejów kościoła ruskiego w Polsce. Został on napisany w 1862 r., a w roku następnym 20 rozdziałów wydrukowano w „Przeglądzie Poznańskim”. Dokończenie pracy wydrukowano dopiero w 1865 r., nie informując o tym autora. Bartoszewicz nie wiedzac o dokończeniu druku, w 1869 r. napisał zakończenie po raz drugi. Prowadził też rozmowy w sprawie wydania całości tekstu przez Józefa Ignacego Kraszewskiego w jego drukarni w Dreźnie. Plany przerwał niespodziewana śmierć Bartoszewicza w listopadzie 1870 r., a szkic jako odrębna praca ukazał się dopiero 10 lat po jego śmierci (Od wydawcy, [w:] J. Bartos ze w i c z, Szkic dziejów Kościoła ruskiego w Polsce, Kraków 1880, s. nlb.).

8 Stanisław Dunin-Karwicki (1640-1724) - cześnik, podkomorzy sandomierski, pisarz polityczny i reformator małopolskiego Kościoła Ewangelicko-Reformowanego. 
było w „Prz.[eglądzie] Pol.[skim]”9. Przynależne honorarium mają za dwa tygodnie wypłacić, odeślę zatem i przez pana Kazimierza. Kronikę Piaseckiego ${ }^{10}$ za kilka dni zaczynają drukować. Zobaczywszy przy niej pracę Drogiego Pana, ucieszyłem się mocno.

Interes Drogiego Pana wielce mnie obchodzi. Jakże gorąco proszę Boga, żebym mógł donieść o pomyślnym rezultacie naszych tu starań. P.[an] Kazimierz ze wszystkimi tu dobrze żyje, więc wiele może zrobić.

Zakończyć muszę moją bazgraninę, bo chciałbym list w tej chwili oddać na pocztę.

Ściskam najserdeczniej Drogiego i Szanownego Pana. - Pani raczki całuję i ukłony Czcigodnemu Ojczulkowi przesyłam.

Pozostaję $z$ najgłębszym szacunkiem

Z. [ygmunt]

P.S. Panu Adamowi ${ }^{11}$ stokrotnie dziękuję za tak ważne przesłane mi wiadomości historyczne o Kapicy ${ }^{12}$, do którego dzieła piszę wstęp. Dziwię się, że nie mam listu od p.[ana] Miłkowskiego ${ }^{13}$.

Obecnie pracy mam tak wiele, że opisać tego nie umiem, o dziele moim, które drukuję, nic nie piszę, bo je osobiście pewno doręczę Drogiemu Panu za 7 tygodni w Warszawie.

Artykuł zamieszczony w „Przeglądzie Polskim” dotyczył dzieła Karwickiego De corrigendis defectibus in statu Reipublicae Polonae.

9 „Przegląd Polski” - miesięcznik wydawany w Krakowie w latach 1866-1914 przez przedstawicieli krakowskiego środowiska naukowego, zwiąanymi z galicyjskimi konserwatystami.

10 Do wydawnictwa źródłowego, czyli Kroniki Pawła Piaseckiego, warszawski historyk napisał obszerny wstęp. J. Barto s zew i c z, Paweł Piasecki, biskup przemyślski, opat mogilski (1579-1649), [w:] Kronika Pawła Piaseckiego, biskupa przemyślskiego. Polski przekład wedle dawnego ręopismu, poprzedzony studyjum krytycznem nad życiem i pismami autora, Kraków 1870, s. III-LXXXVI.

${ }_{11}$ Mowa o ojcu Juliana Bartoszewicza, Adamie (1792-1878).

12 Ignacy Kapica Milewski (1763-1817) - archiwista kancelarii w Brańsku, który na zlecenie Piotr Potockiego robił kopie i odpisy $z$ ksiag grodzkich $z$ terenu Podlasia i północno-wschodniego Mazowsza. Pozostawione przez Kapicę materiały odnalazł, opracował i opatrzył wstępem Zygmunt Gloger. Praca pt. Herbarz Ignacego Kapicy Milewskiego (dopełnienie Niesieckiego) została wydana w Krakowie w 1870 r.

${ }^{13}$ Władysław Miłkowski (1847-1928) - publicysta, wydawca, księgarz, znajomy Zygmunta Glogera z okresu studiów w Szkole Głównej w Warszawie. 


\section{2.}

APŁ, Archiwum rodziny Bartoszewiczów, sygn. 1338, k. 6.

Kraków, dnia18 lipca 1869 r.

\section{Najdroższy Panie!}

List Pana dany Miłkowskiemu odebrałem i serdecznie za niego dziękuję. Z niecierpliwością oczekuję chwili, w której będę mógł uściskać Drogiego Pana w Warszawie, a to nastapi w końcu tego miesiąca. Wszystkie tu moje zajęcia pokończyłem i dzieło moje wydałem, ale nic o nim nie będę pisać, tylko w oryginale przedstawię i złożę Drogiemu Panu, jak przyjadę. Oczekuję teraz na paszport, bo mi tamten wyszedł, a nowy do powrotu w tych dniach nadejdzie; zaniepokoił mnie tylko Drogi Pan zamiarem wycieczki w Kaliskie, bo nużbym Go nie zastał w Warszawie i nie miał sposobności osobistego zaproszenia i namówienia do przejażdżki w moje strony, która by mnie i rodzicom moim wielka sprawiła przyjemność. Nawet umyśliłem sobie projektować, aby Drogi Pan przez ten czas, nim przyjadę, wystarał się o paszport do Jeżewa ${ }^{1}$ (gub. łomżyńska), a $z$ Warszawy pojedziemy razem; będzie to, jak mi się zdaje, najlepiej i najdogodniej, a mam tę nadzieję, że Drogi Pan nie zechce odmówić mnie i rodzicom moim przyjemności powitania Go i w tym roku w domu naszym.

Co do rękopisu od Koźmiana², szkoda, że zaszło takie nieporozumienie, przysłano go $z$ Poznania Estreicherowi, ale nie powiedziano, że do mnie, Estreicher też sądząc, że to pomyłka jakaś, bo nic o tym nie wiedział, odesłał po paru tygodniach rękopis do Poznania, zrobiłem więc znowu kroki tutaj przez ks. Dunajewskiego ${ }^{3}$, aby rękopis otrzymać.

[2] ${ }^{1}$ Jeżewo - wieś na Podlasiu, w guberni łomżyńskiej, nieopodal Tykocina własność rodziny Glogerów.

2 Jan Koźmian (1814-1877) - działacz społeczny, redaktor, publicysta i ksiądz. Był redaktorem naczelnym „Przeglądu Poznańskiego”, ukazującego się w latach 1845-1865. Rękopis, o którym mowa, to wspomniany Szkic dziejów kościoła ruskiego.

${ }^{3}$ Albin Dunajewski (1817-1894) - polski biskup rzymskokatolicki, od 1890 r. kardynał prezbiter, brat Juliana Dunajewskiego, profesora i rektora Uniwersytetu Jagiellońskiego, prezydenta Krakowa i ministra skarbu Austro-Węgier. 
W przedmiocie katedry nic dziś jeszcze stanowczego donieść nie mogę; panowie ci tylko, od których to zależy, odzywali się, $\dot{z}$ e "chociaż zasługami najwieccej odpowiada pan Bartoszewicz ze wszystkich dzisiejszych naszych historyków, ale maja zasade, aby do katedr w tutejszym uniwersytecie przypuszczać tylko ludzi miejscowych krakowskich, choć mniej zasłużonych”. Jest to zasada bardzo śmieszna, tchnie duchem powiatowszczyzny i biurokracji, która tu nad wszystkim panuje, chodzi zaś im o to głównie, aby w skład samych krakowiaków nie dostał się ktoś obcy, który by naruszył towarzystwo wzajemnej adoracji, jakie sami składaja. Niektórzy mówią znowu, że i Szujski nie powinien mieć katedry, bo nie pochodzi $z$ samego Krakowa, a tylko $z$ dalszych jego okolic, a przecież, jak powiadaja, "mamy w samym Krakowie tutaj urodzonych, którzy by wykładać potrafili!!” Tacy ludzie zapomnieli już zupełnie, czym jest uniwersytet, nauka i obowiązki dla kraju, zdaje im się, że Kraków i uniwersytet krakowski są to rzeczy niemające żadnego związku $z$ reszta kraju.

Zeszyt $z$ artykułem o Karwickim przywiozę i honorarium za niego przypadające, mówiłem już o tym $z$ redakcją; a teraz pożegnam Drogiego Pana $z$ błoga nadzieją zobaczenia się z Nim niedługo i wyruszenia razem do Jeżewa. Pani Dobrodziejce i Szanownemu Ojczulkowi ucałowanie rączek i ukłony załączam, a ściskając najserdeczniej Drogiego Pana, pozostaję $z$ najgłębszym szacunkiem

Zygmunt

Adaś S.[tarzeński] ze stryjami swoimi przejeżdżał tędy do Szczawnicy, widziałem go parę godzin.

3.

APŁ, Archiwum rodziny Bartoszewiczów, sygn. 1338, k. 7-8.

Kraków, dnia 3 lutego 1870 r.

\section{Szanowny Panie!}

Przybyłem tu szczęśliwie, mieszkanie znalazłem gotowe, bo je najałem jeszcze, gdym w roku zeszłym stąd wyjeżdżał. Te parę tygodni ubiegło mi niepostrzeżenie, musiałem bowiem w tym czasie 
odwiedzić wszystkich dawnych znajomych, urządzić się w moim mieszkanku i zabrać się do pracy. Pytałem się Łepkowskiego ${ }^{1}$, u kogo mam żądać zwrotu papierów przesłanych w roku zeszłym przez Szanownego Pana do tutejszego uniwersytetu; objaśnił mnie, że są one w ręku profesora i byłego dziekana Kuczyńskiego ${ }^{2}$, który w wydaniu ich sprzecznym być nie może, ale nie byłem jeszcze u Kuczyńskiego.

Byłem w redakcji „Przeglądu Pol.[skiego]”, gdzie na Powidaja ${ }^{3}$ ostro natarłem, że nie uiścił się $z$ całej należności za pracę Szanownego Pana o Karwickim. Powidaj pokazał mi rachunki $z$ ostatnich paru lat i to w nich znaleźliśmy, że za druga część pracy wynosząca półtora arkusza druku, a w roku zeszłym drukowana, przesłał przeze mnie złp 180. Chodziło mi więc jeszcze o część pierwszą, za która wypadało, jak sam Powidaj mówił, stosownie do ilości druku złp 160, czyli zł reń. 40. Otóż za tę część pierwszą drukowana jeszcze w r.[oku] 1868 Powidaj twierdzi, że wręczył zł reń. 40 panu Miłkowskiemu, gdy ten był w Krakowie w m.[iesiącu] grudniu r.[oku] $1868^{\mathrm{go}}$. Miłkowski zatem zapewne całą tę rzecz najlepiej wyjaśni. Powidaj, usiłując usprawiedliwić redakcje przed Szanownym Panem i rozjaśnić to jakieś nieporozumienie, przypominał sobie wszystkie szczegóły związek $z$ tym mające. Więc opowiadał, że pan Miłkowski, będac wtedy tutaj, tj. w grudniu r.[oku] $1868^{\mathrm{go}}$, upominał się o honorarium i za swój artykuł o Albercie brandenburskim, ale wówczas artykuł ten nie był jeszcze drukowanym i do tego Powidaj miał oświadczyć panu Miłkowskiemu, że redakcja ma szczupłe fundusze niezmiernie i jego artykuł wydrukuje, ale bez żadnego honorarium dla niego, inaczej drukować nie będzie mogła wcale. Otóż pan Miłkowski, jak sądzi Powidaj, zgodził się na to, kiedy swego artykułu nie odebrał, a tylko przyją 40 zł reń. dla Szanownego Pana za część $1^{\text {sza }}$ Karwickiego. Wszystko to, jak sądzę, jest tylko jakieś nieporozumienie, które wyjaśni p. Miłkowski, a przy tej sposobności i jemu moje ukłony przesyłam. $Z$ Jeżewa otrzymałem już tutaj 3 listy i na wszystkie odpisałem, w nieobecności mojej jedyną dla matki przyjemnością i rozrywką są moje listy, więc muszę pisać do domu co tydzień długi list i co tydzień dwuarkuszowy odbieram.

$[3]^{1}$ Por. przyp. nr 6 (wprowadzenie).

2 Stefan Ludwik Kuczyński (1811-1887) - fizyk, meteorolog, w roku akademickim 1868/1869 dziekan Wydziału Filozoficznego Uniwersytetu Jagiellońskiego, a w roku akademickim 1882/1883 rektor tej uczelni.

${ }^{3}$ Ludwik Powidaj (1830-1882) - historyk i publicysta, redaktor odpowiedzialny „Przeglądu Polskiego” w latach 1867-1874. 
Dla Pana mam najserdeczniejsze od Rodziców ukłony w ostatnim liście od nich, aż przez Kraków wracaja one do Warszawy. Gustaw ${ }^{4}$ rozłaczył się $z$ Fleurym ${ }^{5}$, ale wydobyć dotąd nic nie mógł dla siostry i siebie. Fleury prosił go, aby sam obmyślał środki dla wydobycia skąd pieniędzy, więc biedny Gustaw siedzi w Szelągówce ${ }^{6}$ i obmyśla, ale czy co $z$ tego będzie, gdy Fleuremu nikt nie chce pożyczyć nawet grosza, las wszystek do gałąki sprzedany, a pieniądze dawno przeputane $^{7}$, ziemi ani łąki sprzedać nie można, bo krajowcom kupować nie wolno, a w dodatku należy się jeszcze rządowi 40000 złp zaległej kontrybucji ${ }^{8}$. Fleurowa miała w tych dniach robić zapis swemu mężowi połowy majątku, bo tak jej on kazał. Kończąc mój list, załączam Pani Dobrodziejce najserdeczniejsze moje ukłony i całej rodzinie Szanownego Pana. Do Adasia S. ${ }^{9}$ bilecik oddzielny załączam, a najserdeczniej ściskając Najdroższego Pana, pozostaję z głębokim i dozgonnym szacunkiem dla Niego.

Zygmunt

P.S. Wiadomej pracy Szanownego Pana oczekuję.

Adres mój: ulica Mikołajska Nº460 dom p.[ani] Żebrowskiej.

\section{4.}

APŁ, Archiwum rodziny Bartoszewiczów, sygn. 1338, k. 9-10.

Kraków, d.[nia] 13 kwietnia 1870 r.

\section{Szanowny Panie!}

Powinienem był dawno już pisać do Drogiego Pana, ale wyczekiwałem z pewnych przyczyn. Przesyłkę ze „Szkicem” dostałem

${ }^{4}$ Gustaw Jaczyński - przyjaciel i sąsiad Zygmunta Glogera.

${ }^{5}$ Ludwik de Fleury (1828-1909) - hrabia, właściciel wsi Kępy nad Biebrza, maż hrabiny Joanny Potockiej (zmarłej w 1870 r.), właścicielki Szelagówki, w której pod koniec życia gościł Julian Bartoszewicz. Z gospodarzem połaczyły warszawskiego historyka wspólne zainteresowania i pasja kolekcjonerska.

${ }^{6}$ Szelagówka - dobra na Podlasiu, w kluczu zakątkowskim, w powiecie łomżyńskim.

7 Przeputać - zmarnować, roztrwonić, przepuścić.

8 Mowa o kontrybucji, jaka nałożono na majątek po powstaniu styczniowym.

9 Prawdopodobnie chodzi o Adama Starzeńskiego.

[4] ${ }^{1}$ Mowa o wspominanym wcześniej Szkicu dziejów kościoła ruskiego w Polsce. 
w całości, a obecnie przepisuję co potrzeba, w czym mi Adaś niemało dopomaga. Dzieło jednak nie będzie się zaraz drukować, ale zawsze wyjdzie w ciagu kilku miesięcy. Byłem u Powidaja i ostra wypowiedziałem mu prawdę, więc natychmiast miał pisać do p.[ana] Miłkowskiego, jakby tu była potrzeba pisania. Powiedziałem mu, żeby nas $z$ Kongresówki i Warszawy nie sądził po galicyjsku, wedle siebie; że p.[an] Miłkowski pieniędzy nie brał, bo będąc wtedy w Krakowie, stał w moim mieszkaniu, byłem i świadkiem jego utyskiwania na redakcję „Przeglądu”, że płacić mu nie chciała i sam panu Mił.[kowskiemu] pożyczyłem na drogę do Warszawy, więc pieniędzy nie brał. Powidaj też łapał się na każdym kroku, sam się przyznał, że wcale nie pamięta chwili, w której by płacił p. Miłkowskiemu, lecz że pamięta, jak należność za część I ${ }^{\text {sza }}$ obrachował na złr. 40 i w książce wydatków ma takowe 40 złr. zapisane. Przekonałem go, że książką jego wydatków sa jakieś nieporządne brudne szpargały, a w nich było zapisane złr. 45, więc cyfra niezgodna $z$ ta, jaka miał p.[anu] M.[iłkowskiemu] wypłacić, to jest złr. 40. Powiedziałem mu, że pójdę do Tarnowskiego ${ }^{2}$, a ten $z$ jego przyczyny usłyszy to, czego pewnie jeszcze od nikogo nie słyszał. Wczoraj spotkałem Powidaja, idąc do niego, mówił, że już otrzymał od pana Mił.[kowskiego] odpowiedź i upewniał, że wkrótce wyśle pieniądze do Warszawy. Jeszcze pozostaje mi wydobyć sam „Przegląd”, ale wprzód muszę dokładnie wiedzieć, co Szanowny Pan ma, a co Mu brakuje $z$ tego pisma. List przywieziony przez Adasia doręczyłem panu L. Siemieńskiemu ${ }^{3}$ i mam polecone ukłony od niego załączyć.

Od senatu akademickiego odebrałem papiery Szanownego Pana i przesłać je lub przywieźć nie omieszkam, ale dziś wziął je ode mnie Adaś, aby księciu Jerzemu Lubomirskiemu ${ }^{4}$ pokazać spis prac Drogiego Pana, bo był tego bardzo ciekawym i wiele wypytywał się. Adaś buduje na tym nadzieję jakiejś posady, lecz ja miałem czas bliżej się tu przekonać o położeniu rzeczy, poznałem charakter i sposób myślenia księcia Jerzego i wiem, ile straci na tym zakład

${ }^{2}$ Stanisław Tarnowski (1837-1917) - historyk literatury, krytyk literacki, publicysta, przywódca krakowskich konserwatystów, profesor Uniwersytetu Jagiellońskiego, dwukrotny rektor (1886/1887, 1899/1900). Współzałożyciel i redaktor „Przeglądu Polskiego".

${ }^{3}$ Lucjan Siemieński (1807-1877) - pisarz i poeta, krytyk literacki, tłumacz, założyciel i członek Akademii Umiejętności w Krakowie.

4 Jerzy Henryk Lubomirski (1817-1872) - krakowski działacz polityczny, członek dziedziczny austriackiej Izby Panów, poseł na sejm galicyjski, kurator Ossolineum. 
imienia Ossolińskich ${ }^{5}$, że przeszedł pod opiekę księcia Jerzego, który chciałby otoczyć się ludźmi uczonymi, ale wierzącymi ślepo w jego zasady polityczne i naukowe (dość płytkie). Przy tym jest wielkim biurokrata, dziwakiem i nudziarzem $\mathrm{w}$ codziennych stosunkach, zamęcza tym swoich podwładnych w zakładzie imienia Ossolińskich. Ma w Warszawie być z Krakowa niejaki Dębicki ${ }^{6}$, półliterat, wielki księcia przyjaciel, dobry katolik, ale ślepy arystokrata i w krew herbowa wierzacy jak w Boga, zresztą dobry człowiek, chce złożyć wizytę Szanownemu Panu. Dębicki z Helclem ${ }^{7}$ byli założycielami „Warowni krzyża”. Bardzo podzielam każda myśl bronienia wiary, szkoda tylko, że tu nie umiano zapatrywać się na to ze stanowiska narodowego i wobec opinii publicznej (jakkolwiek niewiele tu wartej) zwichnięto rzecz, która mogłaby w innym razie znakomite i pożądane wydać owoce. Udzielony mi statut „warowni krzyża” dla Szanownego Pana prześlę w innym liście osobno i wkrótce, bo $\mathrm{w}$ tym nie mieściłby się. Był mi on doręczonym przez panią Żebrowską i pannę Kazimierę, po której odjeździe jakoś dziwnie pusto Kraków nam się tu wydaje.

Jak Dębicki będzie u Drogiego Pana, to jako przyjaciel księcia J.[erzego] L.[ubomirskiego] nie powinien wiedzieć, co ja pisałem o księciu, z którym także się znam trochę. O wielu innych rzeczach nie mam miejsca tu pisać, ale wszystko opowie Adaś powracajacy do Warszawy na święta. Miałem myśl przedrukować niektóre artykuły Szanownego Pana $z$ Enc.[yklopedii] powsz.[echnej], np. „Ruś" 9 , co można by wydać w formie oddzielnej broszurki, ale nie mogac tego robić bez pozwolenia autora i nie znając Jego stosunku z nakładca Enc.[yklopedii] p.[owszechnej], będę prosił o Jego

${ }^{5}$ Zakład im. Ossolińskich - zakład ufundowany w 1817 r. we Lwowie przez Józefa Maksymiliana Ossolińskiego (1748-1826), bibliofila i kolekcjonera, którego zbiory stały się zalążkiem przyszłych zbiorów. Zakład został otwarty we Lwowie w 1827 r. i stał się jednym $z$ najważniejszych instytutów gromadzących dorobek piśmienniczy narodu polskiego oraz ośrodkiem polskiego życia naukowego.

${ }^{6}$ Ludwik Zygmunt Dębicki (1843-1908) - pisarz, dziennikarz, publicysta, przez wiele lat zwiąany $z$ krakowskim „Czasem”, obrońca polskiego katolicyzmu.

7 Antoni Zygmunt Helcel (1808-1870) - prawnik, historyk, polityk i publicysta. Założyciel krakowskiego stowarzyszenia katolickiego „Warownia Krzyża”.

8 „Warownia Krzyża” - organ towarzystwa o tej samej nazwie założony i kierowany przez A. Helcla, a redagowany przez Zygmunta Dębickiego - wyszły tylko dwa podwójne zeszyty.

9 Hasło „Ruś” opublikowano w 22. tomie wspomnianej encyklopedii: J.B. [Julian Bartoszewicz], Ruś, [w:] Encyklopedyja powszechna, t. XXII, Warszawa 1866, s. $513-531$. 
zdanie i wyjaśnienie w tej sprawie, a może zrobi się coś pożytecznego i korzystnego. Nikt jednak nie ma wyobrażenia o literackiej stagnacji, jaka panuje w Galicji, książki wychodzą tylko nakładem osób prywatnych i tych nikt nie kupuje. Zawadzki ${ }^{10} \mathrm{w}$ Wilnie więcej sprzedawał książek w swojej księgarni przez miesiąc niż wszyscy księgarze lwowscy przez cały rok.

Ciepłe dni kwietnia przypominaja mi już lato, więc i nadzieję zobaczenia się naszego, a spodziewam się, że Drogi Pan nie odmówi nam swojej bytności w Jeżewie i tego lata, cieszę się więc tym już $z$ góry i wyobrażam chwile, kiedy zasiądziemy znowu pod starymi lipami jeżewskimi.

Szanownej Pani Dobrodziejce rączki całuję i całemu zacnemu domowi wesołych świąt przesyłam. Miłkowskiemu także przyjacielskie pozdrowienia zasyłam.

Drogiego zaś i Szanownego Pana ściskam najserdeczniej i z głębokim pozostaję szacunkiem.

Zygmunt

\section{5.}

APŁ, Archiwum rodziny Bartoszewiczów, sygn. 1338, k. 11-12.

Jeżewo, dnia 2 października 1870 r.

\section{Szanowny Panie!}

Za serdeczne uściśnięcie w liście Jego do mojej matki stokrotnie dziękuję. Czemuż Bóg nie dał nam tego lata powitać Czcigodnego Pana w progu naszego domku na Podlasiu, ale mamy błoga nadzieję, że do przyszłego lata zginą nawet wspomnienia dzisiejszej jego słabości, która tego przyczyną. Matka pisze długi list do Pana, ja zaś krótki, bo najdalej za tydzień mam zamiar być w Warszawie i kilka dni tam zabawić. Do Kraszewskiego ${ }^{1}$ pisałem, że Szanowny Pan zgadza się na honorarium 200 rs. i że rękopis dzieła stosownie do

${ }^{10}$ Mowa o firmie wydawniczo-księgarskiej założonej w Wilnie przez Józefa Zawadzkiego (1781-1838), po jego śmierci prowadzonej przez synów Adama i Feliksa.

[5] ${ }^{1}$ Józef Ignacy Kraszewski (1812-1887) - pisarz, publicysta, wydawca i działacz społeczny. Jego utwory cieszyły bardzo dużą popularnością wśród społeczeństwa polskiego. 
jego życzenia złożony u Estreichera. Starzeński przeze mnie zapytywany donosił mi, że dotąd nie zgłosił się Kraszewski po ten rękopis $-z$ jakiej przyczyny? Wiedzieć nie moge - wszak sam pisał, że ma pewna nadzieję znaleźć nabywcę za rs. 200 i dawał do zrozumienia, że on $z$ Żupańskim ${ }^{2}$ o tym myśli. Ludzie tacy jak Żupański to sa tylko handlarze, którzy podczas wojny grosz zamykają w szkatule i wstrzymuja swoje przedsiębiorstwa. Sądzę, iż to jest przyczyną, że Kraszewski nie zgłasza się po rękopis, a takim sposobem nawet w naszej literaturze wojna pruskofrancuska ${ }^{3}$ czuć się dała. Jeżeli Kraszewski do listopada nie nabędzie rękopisu, to ja sam zajmę się jego wydaniem w Krakowie, dokąd mam zamiar pojechać w grudniu, ale tylko na parę miesięcy. O wszystkim będziemy mogli pomówić przy osobistym widzeniu się, które zapewne wkrótce nastąpi. Takie mnóstwo przybyło mi w ostatnich czasach ciekawych historycznych papierów, że przynajmniej przez trzy wakacje będzie Szanowny Pan miał co przeglądać; prawda, że przez kilka tygodni nie zsiadałem $z$ bryczki, robiacc archeologiczne poszukiwania w dość oddalonych okolicach. Do historii Podlasia w w.[iekach] XIV i XV, do założenia jego wszystkich kościołów i klasztorów nieoszacowane mam materiały. Papierów dyplomatycznych het.[mana] Branickiego ${ }^{4}$ przybyło także dosyć, kilka rzeczy przywiozę do Warszawy; a teraz ściskając najserdeczniej Szanownego Pana i rączki, całując Pani Dobrodziejce, $z$ nadzieja zobaczenia się wkrótce, kończę moją bazgraninę wynurzeniem najgłębszego szacunku dla Ich domu.

\section{Zygmunt Gloger}

P.S. Gustaw Jaczyński ukłony swoje załącza, bawi on ciagle u nas, nie mogąc do tej pory ani w części wydobyć swojej należności u Fleurego, który jak najbezczelniej postępuje ze swymi wierzycielami.

2 Żupański Jan Konstanty (1804-1883) - księgarz i wydawca, właściciel księgarni i firmy wydawniczej w Poznaniu, należącego, jak wiadomo, do zaboru pruskiego.

${ }^{3}$ Wojna prusko-francuska trwała od 19 lipca 1870 do 10 maja 1871 r., zakończyła się klęską Francji i utratą na rzecz cesarstwa niemieckiego Alzacji i Lotaryngii.

${ }^{4}$ Mowa o tzw. archiwum białostockim hetmana Jana Klemensa Branickiego (1689-1771). Szerzej o ocalonym od zniszczenia archiwum i pracach związanych z porządkowaniem odnalezionych materiałów: I. Florczak, Źródła do dziejów Podlasia w Archiwum rodziny Bartoszewiczów, „Studia z Historii Społeczno-Gospodarczej XIX i XX wieku” 2015, t. XV, s. 169. 


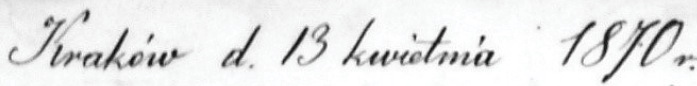 aobr, $10<10$ \\ Srannowny Parie!

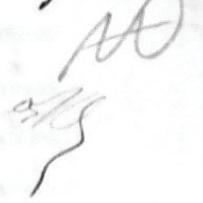

$-i^{2}$

C)

Cournineme lyt dawnojúx pisac' do 'Drogié qo Cana ale nycrekuratem z pevenych prycrym. Freesythe ze "Sxkicem "dostatem w catosici a drec.

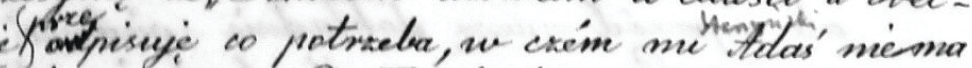
To dopomaga. Drieto jednat nie bedrie sie sarar drukoveré ale sausse uyjidrie w ciágu kilku mie siecy: Byterv u Povidaja i astra nupo.

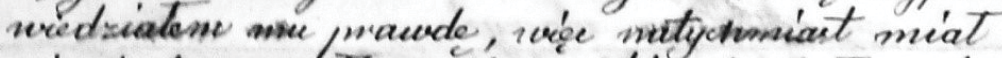

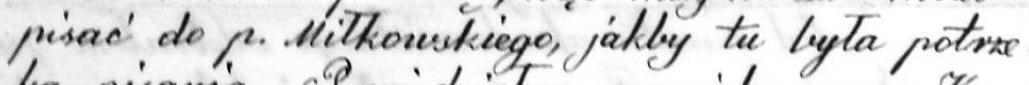
ba pisamia. Convidxiatem mu xeby nas stion gresómki i Mansany wi sadrit po galicyjistiu, wodle sielie; ie p. Nitkouski niemedny mie brat,

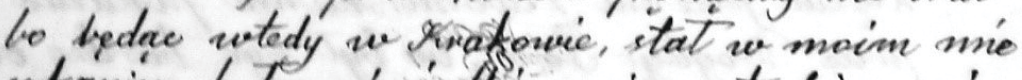

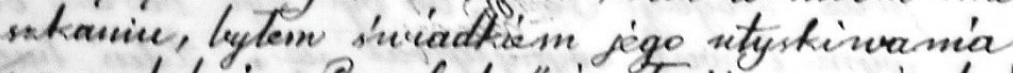
na rodakife "Prreglgdu" pe placic ame me cheía la isam pame Miti poriyarytem ma droge do Tha savury, wée piémédry nie brat. Powidaj tor la pat ne na kardym kraker, sam see prymmat, we meale nie pamieta chuili w itorejly ptacil p. Nithomkiemui leck ie pamiéta jak nabinos

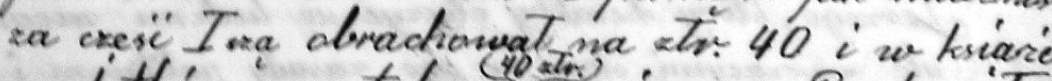

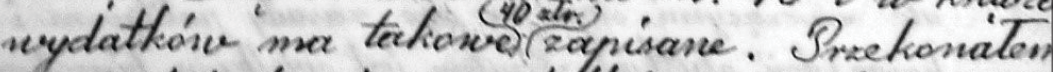

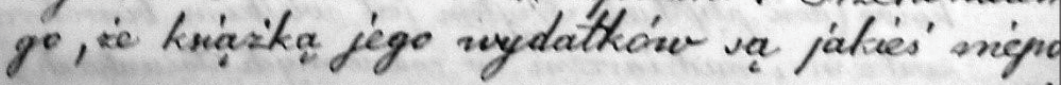
rract

1. Archiwum Państwowe w Łodzi, Archiwum rodziny Bartoszewiczów, sygn. 1338, k. 9 


\section{Bibliografia}

\section{ŹRÓdeA ARCHIWALNE}

Archiwum Państwowe w Łodzi

Archiwum rodziny Bartoszewiczów, sygn. 807, 1338.

\section{OpRacowania}

Bartoszewicz J., Paweł Piasecki, biskup przemyślski, opat mogilski (1579-1649), [w:] Kronika Pawła Piaseckiego, biskupa przemyślskiego. Polski przekład wedle dawnego rękopismu, poprzedzony studyjum krytycznem nad życiem i pismami autora, Kraków 1870, s. III-LXXXVI.

Birkenmajer A., Estreicher Karol, [w:] Polski słownik biograficzny, t. XI, Kraków 1946, s. 312-315.

Daszyk K.K., Historiografia krakowska doby zaborów. Główne kierunki badań $i$ interpretacji narodowej przeszłości, [w:] Historiografia Krakowa i jej twórcy, Kraków 2005.

Florczak I., Nauczyciel w służbie państwowej. Między poczuciem obowiazku a własnymi aspiracjami. Przypadek Juliana Bartoszewicza (1821-1870), [w:] Między irredenta a kolaboracja. Ugoda, legalizm, lojalizm. „Dusza urzędnika” - ludzie $i$ ich kariery, red. A. Szmyt, Olsztyn 2015, s. 51-65.

Florczak I., Źródła do dziejów Podlasia w Archiwum rodziny Bartoszewiczów, „Studia z Historii Społeczno-Gospodarczej XIX i XX wieku” 2015, t. XV, s. 161-176.

Gierowski J.A., Józef Szujski jako historyk czasów nowożytnych, [w:] Spór o historyczna szkołę krakowska. W stulecie Katedry Historii Polski UJ 1869-1969, red. C. Bobińska i J. Wyrozumski, Kraków 1972, s. 83-93.

Gloger Z., Obrzędy rolnicze, „Biblioteka Warszawska” 1867, t. II, s. 274-287.

Grabski A.F., Warszawskie środowisko historyczne $w$ okresie międzypowstaniowym, „Kwartalnik Historyczny” 1971, nr 4, s. 892-899.

Hulewicz J., Seminarium historyczne UJ w latach 1861-1918, [w:] Spór o historyczna szkołe krakowska. W stulecie Katedry Historii Polski UJ 1869-1969, red.

C. Bobińska i J. Wyrozumski, Kraków 1972, s. 47-69.

J.B. [Julian Bartoszewicz], Ruś, [w:] Encyklopedyja powszechna, t. XXII, Warszawa 1866, s. 513-531.

Kieniewicz S., Schmitt Henryk (1817-1883), [w:] Polski słownik biograficzny, t. XXXV, Warszawa-Kraków 1994, s. 559-563.

Koczarska-Bąk C., Łepkowski Józef, [w:] Polski słownik biograficzny, t. XVIII, Wroclaw 1973, s. 339-343.

Komorowska T., Zygmunt Gloger. Opowieść biograficzna, Warszawa 1985.

„Krynica Wiadomości”. Korespondencja Józefa Kremera z lat 1834-1875, oprac. Z. Sudolski, Kraków 2007.

Michalak H.S., Józef Szujski 1835-1883. Światopogląd i działanie, Łódź 1987. 
Mitkowski J., Józef Szujski jako historyk średniowiecza, [w:] Spór o historyczna szkołe krakowska. W stulecie Katedry Historii Polski UJ 1869-1969, red. C. Bobińska i J. Wyrozumski, Kraków 1972, s. 71-81.

Od wydawcy, [w:] J. Bartoszewicz, Szkic dziejów Kościoła ruskiego w Polsce, Kraków 1880.

Olszewicz W., Życie i praca Zygmunta Glogera, [w:] Zygmunt Gloger - badacz przeszłości ziemi ojczystej, Warszawa 1978.

Studia z dziejów Wydziału Filozoficzno-Historycznego Uniwersytetu Jagiellońskiego, red. S. Mikucki, „Zeszyty Naukowe Uniwersytetu Jagiellońskiego. CXXXIX. Prace historyczne" 1967, z. 16.

Szujski Józef (1835-1883), [w:] Polski słownik biograficzny, t. LXIX, WarszawaKraków 2013, s. 176-187.

Turczynowiczowa M., Kolberg Henryk Oskar, [w:] Polski słownik biograficzny, t. XIII, Wrocław, 1967-1968, s. 300-304.

Żurkowa R., Zygmunta Glogera związki z AU w Krakowie, „Rocznik Biblioteki Polskiej Akademii Nauk w Krakowie" 1973, t. XIX, s. 135-147. 